\title{
From Christianity to African Religion and back again
}

\author{
A M Meiring ${ }^{1}$ \\ (University of Pretoria)
}

\section{ABSTRACT}

\section{From Christianity to African Religion and back again}

This article passes from Christianity to African Religion and back again, in order to gain new insight on reconciliation. Traditional Christian reconciliation models are valuable but also contextual and limited; thus new models should be sought. African myths of community, acceptance and rebellion offer alternative ways of understanding reconciliation. When evaluated according to the principles of integration and transcendence, these myths meet the criteria of better religion and emphasise Christian notions that are often ignored in tradition Christianity. These new African-inspired insights can be used in Christian liturgy as a number of examples prove.

\section{INTRODUCTION}

John Dunne (1978:ix) once said that "The holy man of our time, it seems, ... [is] a man who passes over by sympathetic understanding from his own religion to other religions and comes back again with new insight to his own. Passing over and coming back, it seems, is the spiritual adventure of our time". In this article I want to experiment with this adventure and try to pass over from Christianity to African religion ${ }^{2}$ with the aim of gaining new insight.

Specifically, I want to find out what insight African Religion offers on the issue of reconciliation. Reconciliation is very relevant both for the South African context and for Christianity as a whole as it determines our understanding of Jesus Christ and exactly how he

1 Post-graduate student, Department of Science of Religion and Missiology.

2 There has been some debate in the past on whether all the different peoples of Africa have one religion or whether they all have different religions. There is enough reason to speak of African religions - there are about two thousand African people groups (tribes), and each has its own religious system. Still, most scholars agree that African religion is "one in its essence" although there are a variety of expressions of that one belief (Magesa 1997:15-16; Mbiti 1969:1-2, 12; 1998:141; 2005:2; Parrinder 1962:10-11; Smart 1989:298). 
achieved what. Of course, the reconciliation by Christ has been studied thoroughly. The Nicene Creed articulated that Jesus became flesh: propter nos homines et propter nostrum salutem (for us human beings and for the sake of our salvation), and since then countless Christian theologians through the centuries have ventured to describe exactly how Jesus reconciled us to God. Most influential among these were the ideas developed by Augustine, Anselm, and Abelard ${ }^{3}$.

The best of these "reconciliation models" were contextual and explained the reconciliation in the language and images of their time. Anselm, for example, did exactly that: he used the prevailing juridical-rational idea of order to explain reconciliation to his $11^{\mathrm{th}}$ century audience. But this contextual nature of all reconciliation models also limits them. Thus, Hans Küng (1974:424) asked:

$\ldots$ if this was permitted to medieval theology, can we forbid to modern theology its own fresh approach? We can no more commit ourselves now than in New Testament or patristic times to a particular conceptual framework - whether juridical, cultic, metaphysical, or even scientific, technical, physiological, sociological - for the interpretation of the highly complex event of the redemption.

\section{AFRICAN RECONCILIATION MODELS}

Reconciliation is at the heart of all religions. Still, African Religion is so this-worldly, practical and humane, that everything is about relationships, strengthening relationships and healing relationships. In fact, the affairs of humans are considered to be all important. Africans believe that conflict between humans brings about conflict between humans and God; reconciliation between people also causes reconciliation with God. The horizontal dimension seems to precede the vertical (Bediako 1995:101; Ndungane 2003:101; Van Niekerk 1982:24).

3 Augustine believed that Christ triumphed over the devil and defeated it on the cross. He likened the devil to a mouse, the cross to a mousetrap, and Christ to the bait. Anselm developed the idea of objective substitution whereby Christ pays the ultimate price for the sin of the world, in order to satisfy and restore God's honour. According to Abelard's subjective theory Christ achieved reconciliation by revealing God's love for creation and setting an example for the rest of humanity. 
Hence, African religion offers a wealth of reconciliation models, myths and rituals that may deepen our understanding of reconciliation. These ideas are expressed in a variety of ways, in proverbs, short statements, songs, prayers, names, stories and religious ceremonies, and difficult to categorize. But if one considers the myths behind these reconciliation rites, a number of themes emerge.

Some of these themes closely resemble the ideas of Augustine, Anselm and Abelard, for example the various myths of expulsion, propitiation and communion. Other themes offer something completely different:

\subsection{Myths of Community (ubuntu)}

In their myths about the "genesis" of things, it is significant that Africans invariably teach that the first appearance of people was as a group, or as a company. In these myths, whether the first people came out of a bed of reeds or a hole in the ground, it is invariably a community of men, women, children and animals that appear (Setiloane 2000:20).

A Zulu myth explains how the community was God's solution for brokenness:

... a mischievous young man was punished by iNkosi by being sent to earth through a hole in the sky. After the hole had been opened in the floor of the sky, iNkosi tied an intestine or umbilical cord around the young man's waist and lowered him to earth. The young man then cut himself loose from the cord connecting him to the sky by means of a reed. Later, when iNkosi checked on the lad through the same sky-opening, he found him wasting away from loneliness. Since iNkosi was himself the father of the boy, he decided to send the most beautiful young sky maiden to comfort him and be his wife. She too was lowered to earth by means of a cord and she found the youth by a banana plant. When the boy saw the girl, he realised from her great beauty that she had come from the lord-of-thesky. He cut her cord as he had cut his own, whereupon iNkosi drew it back into heaven and closed the hole in the floor of the sky. Henceforth people could multiply on earth and were no longer lonely, seeking to return to heaven (Thorpe 1991:37).

It is interesting that the problem of separation from God was solved by God himself, but in a surprising way. Instead of restoring 
the previous relationship, a new community was created which seemed to have satisfied all parties.

According to African Religion the community is the arena for human interaction. If tensions arise they must be dealt with in the community. It follows that the community is also the arena where forgiveness and reconciliation can and must take place. The crucial requirement, always, is the maintenance of order and balance within the group; no one individual is permitted to disrupt the whole (Thorpe 1991:110).

There are countless examples of these kinds of reconciliation rituals between individuals. Often the first option is simply to "make friends again". This can be achieved by two enemies clasping their hands with chyme ${ }^{4}$, washing real or symbolic wounds ${ }^{5}$ or by simple dialogue $^{6}$. Sometimes a peace tree is planted or a peace child identified to remind all parties of the restored community (Ngubane 2004).

Sometimes the community facilitates reconciliation between conflicting parties. John Mbiti (2005:1) related how the whole community would involve themselves in the marital problems of a husband and a wife. Often, when a wife left her husband to return to her family, this would be recognised by both families as an invitation to become involved in the couple's marital affairs and they would go through considerable effort to try to reconcile the husband and wife.

$4 \quad$ The clasping of hands with chyme (mosoang)

When two enemies want to reconcile, they will clasp their hands with chyme as a sign of reconciliation. Chyme is used because it has the same cooling effect as water. After this ceremony of reconciliation, all the village will eat together as witnesses (Tlhagale s a: 71).

\section{Bodily injury}

A perpetrator may also wash the real or symbolic wounds of his or her victim with water from a nearby river. By doing this he or she acknowledges responsibility and guilt for the offence, and binds him or herself never to do it again (Ngubane 2004:1).

\section{$6 \quad$ Speaking of good lost days}

Enemies could be told to speak to one another of potential good days (parties or meetings) that were lost due to the animosity. They will soon realise how much their animosity is costing them and undoubtedly stop their quarrelling (Ngubane 2004). 
Reconciliation through community is often established through libations, sacrifices and medicines. The libations of water, rum or beer and sacrifices consisting of burnt meat reconcile two parties (one of which may be the ancestors) through eating and drinking together. Blood plays an interesting part in establishing this community as it is believed that the blood of a sacrificial animal is a symbol of life. If blood is offered to the ancestors it brings them back to life. Alternatively, blood can also represent the place where life and death meet and be a pathway between human beings and God (Ndwandwe 2000:211; Parrinder 1962:87-88; Tlhagale s a: 11, 24).

Medicines work in a more symbolic way. Roots or leaves or parts of animals or birds are boiled in water or pulverised in fire to form the basic ingredients of medicine. All of these elements: plants, animals, water and fire - represent the major forces of nature. The vapour and smoke produced in boiling and pulverising these medicines symbolise air. In applying them to the human body, the link between nature and humanity is established in a very intense way. This linkage is also realised through the use of charms and amulets (Magesa 1997:209-211).

\subsection{Myths of Acceptance}

Africans deal with the sources of tension and conflict in different ways. Usually they would try to expel or exorcise all kinds of evil thought to be at work in the community. But sometimes, an opposite ploy is followed. These are the myths of acceptance.

According to these myths, evil and troublesome spirits can be neutralised by being accepted and accommodated in the community. Especially when the evil spirits are believed to be the ghosts of people who have died who could not become ancestors or who are not properly recognised as such. Through sacrifices and offerings, the erection of special ancestor huts and by seeing to it that neglected obligations are carried out, the ghosts are not destroyed but enabled to enter into an enduring relationship with the living (Magesa 1997:205-206; Thorpe 1991:57).

Chirevo Kwenda (1999:1-8) described the Chihamba cult of the Ndembu (Zambia). A disqualified and therefore protesting ancestor would capture an ancestress (this is called the "mode of Chihamba') and she in turn catches or afflicts some her family members. In an elaborate ritual, the protesting ancestor then uses the 
ancestress as a surrogate to produce a new clan for him, while the afflicted member of her family is initiated into the newly established clan. The ancestress is afterwards freed from the protesting ancestor and the protesting ancestor gains a new family and ancestorhood.

\subsection{Myths of Rebellion}

African myths offer surprisingly different solutions than one would expect. This is the case with the myths of rebellion. According to traditional African thought, the community can be stabilised and reconciliation can be achieved if opportunities are created for people to vent their feelings and challenge the establishment. Accordingly, some African groups would organise rituals of rebellion.

During these rituals and festivals all power structures and communal customs would be challenged. This could for example take the form of ritual transvestism and asexuality (in funeral rites and divination rituals), ritual killing of the new chief (as done in installation rites), ritual hostility between social groups (as happens between the escorting bands of bride and groom or between joking groups), and the ritual use of obscene language (in joking relationships) (Magesa 1997:238-240).

Laurenti Magesa (1997:238) explains that in normal circumstances, what is different must not be needlessly confused. The male and female sex or the intensity and weakness of the life force in a ruler, for example, must be clearly distinguished in daily life for the sake of order. However, sometimes the difference needs to be temporarily blurred through ritual to underline its importance when the ritual is over.

Parrinder (1962:85-86) reports on these rites in Ghana, Togo and Nigeria. During the annual purification rites (which Parrinder compares to the Roman Saturnalia) the people act and speak licentiously, insulting the king, shouting sexual phrases at passers by and running around naked. After the festival, order is restored and the symbols of the gods are scrubbed and cleaned at the river and returned to their shrines.

The reason for this kind of rite was explained by an old priest:

Our forbears ordained a time, once a year, when every man and women, free man and slave, should have freedom to speak out just what was in his head, to tell their neighbours just what they thought of them and of their actions, and not only their 
neighbours, but also the king or chief. When a man has spoken freely thus, he will feel his sunsum (soul) cool and quieted.

(Parrinder 1962:86)

According to Mircea Eliade (1958:359) these rituals bring back the mythical chaos that existed before the creation, in order to repeat the creation:

... for a time man goes back to the amorphous, nocturnal state of chaos that he may be reborn, more vigorous than ever in his daylight self. ... [Man] hopes, by identifying himself with formless, pre-cosmic existence, to return to himself restored and regenerated, in a word, "a new man".

\section{APPRAISAL}

Fascinating as they are, the question remains as to whether these African Religion myths offer new insight into reconciliation. Are they useful in valid in our context, and what criteria should be used to determine this?

Kobus Krüger (1995:110) developed a criterion based on integration $^{7}$ and transcendence ${ }^{8}$ to evaluate a religion or an expression thereof that does not depend on a normative, confessional departure point. All religions are not equal - better religions are both integrative and contextual, and transcending, making a difference for the better. Furthermore, if these myths are to be useful to us, they must be compatible with the main themes and values of Christianity. They should also integrate with and enrich Christian thought.

\subsection{Community}

The myths of community meet the standards of Krüger's criterion. This model of reconciliation simply teaches that the establishment and maintenance of a community is already reconciliation ${ }^{9}$. Its

7 According to the principle of integration, a religion should be clear and comprehensive; this implies that a religion should be coherent, simple and straightforward, link up with existing thinking and cover the facts.

8 The transcending principle requires a religion to be perspectival, relative and historical, rely more on authority and less on force, be stimulating and make a difference for the better.

9 The concept of community or ubuntu usually functions in a microstructure. I agree with Desmond Tutu (1999:35) that this should also be found in larger structures. 
strength lies in this simplicity, making it useful to members of different cultures and worldviews. There are no intricate and esoteric presuppositions, nor bloody sacrifices. God created community as a means of reconciliation. It is easy to understand, and one can be guided by it. The idea that the community can bring about reconciliation integrates well with the this-worldly focus of African Religion. In addition, these myths achieve reconciliation and do make a difference for the better (Meiring 2005:159-160).

It also integrates well with Christian thought. Desmond Tutu (1996:xiii) wrote with his characteristic sense of humour:

Adam was having the time of his life in the Garden of Eden. He enjoyed his work as the primal gardener. The animals loved him and lived in an idyllic, undisturbed harmony. Everything was lovely in the garden. No, not quite. God looked on his human creature and was concerned, for his life was not all unalloyed bliss. God said, "It is not good for man to be alone". And so God asked Adam to choose a mate for himself among the animals which paraded before him in procession. God would ask his human friend: "What about this one?" Adam would reply: "Not on your life! No, thank you!" And so God decided to put Adam to sleep and produced from his rib that delectable creature, Eve; and when Adam awoke he exclaimed: "Wow! This is just what the doctor ordered".

Tutu explains that the story of Adam and Eve relates a fundamental truth about humans - that we are made to live in a delicate network of interdependence with one another, with God and with the rest of creation. According to Tutu, a solitary human being is a contradiction in terms (1996:xiv): "A totally self-sufficient human being is ultimately subhuman. We are made for complementarity. ... We need each other to become fully human". Thus, all efforts to create, recreate or restore the community boils down to reconciliation with both the members of society and with God. African thought sees that the relationship with humans and the relationship with God are inseparable.

Western theologians like John Milbank (1997:273-274) and Rosemary Ruether (2002:xv) also asserts that the idea of community is thoroughly Christian, and that Christ overcomes evil in community with his followers, providing a memory of perfect community and a new language of community. 
The all-importance of the community also implies that even the offender's wellbeing is an important part of reconciliation. It is only once the offender's dignity is restored, that reconciliation can take place (Ndwandwe 2000:214).

This emphasis on community may be more needed than we might think. According to Thorpe (1991:120) loneliness may well be one of the most devastating diseases of modern people as the Western emphasis upon individual rights has swung the pendulum so far off-centre that many people are no longer able to recognise the fact of their right to belong. As a result, belonging to a community, to a tribe, to a family group, may go a long way towards combating the disease of loneliness which threatens to destroy many Westerners.

The idea of ubuntu also inspires personal growth. According to Tutu (1999:35) a person with ubuntu is open and available to others, affirming of others, and does not feel threatened because others are able and good. He or she has a proper self-assurance that comes from knowing that he or she belongs to a greater whole and is diminished when others are humiliated or diminished, when others are tortured or oppressed, or treated as if they were less than who they are.

Thus, there is a broad consensus among theologians that traditional Western Christianity can learn a lot from the African focus on the community (Daneel 1989:272; Crafford, Boshoff \& Daneel 84:48). Setiloane states that: "Christianity could be enriched immensely if it were to learn from African tradition about community, that is, of the very essence of being" (Setiloane 2000:57).

On the other hand, if the community is exaggerated there seems to be at least some hazards. René Girard (1982) found in his study on scapegoats that when a community is faced with a universal threat, it usually attempts to counter this threat by identifying an innocent scapegoat or scapegoats (as was often done to the Jews in Europe). Girard sees the same pattern in the Bible, with the important distinction that the Biblical accounts always reject and protest against the pattern of scapegoatism ${ }^{10}$. The notion that

10 Girard maintains that whenever someone is made into a scapegoat in the Bible, his or her innocence is pointed out. This is true of Psalm 35, Isaiah 53, 
scapegoats can guarantee the safety of the community is exactly the kind of evil that Jesus came to expose and confront (Girard 1982:719, 125-140).

Girard (1982:221) further explains that Jesus not only uncovered the practice of scapegoatism, but also challenged people to take responsibility for their own lives and welfare. Wolfgang Huber (1993:573-591) also emphasises the idea that communities can inhibit responsibility and calls for an ethics of responsibility and collective accountability where Christians are responsible to and for God, as well as to and for humans. Huber's concern is that accountability and collective accountability should never be ignored for the sake of a community.

Thus, while the idea of reconciliation through community enriches Christianity, the community should never be exaggerated to the extent that it falls back on the pattern of scapegoatism but rather even the closest community should allow its members to take responsibility for their actions (Meiring 2005:181-182).

\subsection{Acceptance}

The idea, that evil and strife can be tamed and accepted into the community is the exact opposite of what the expected Christian response would be. Christianity traditionally sees the world in such a dualistic way, that acceptance of evil is beyond conception. But while Africans would often try to expel evil, accommodating that evil is always another option. Through the Chihamba cult troublesome ancestors are given their own descendents and have their own special huts built (Meiring 2005:200).

The myths of acceptance are both integrating and transcending. They are simple, coherent and link up with the African holistic worldview and its view on $\sin ^{11}$. Simultaneously, it is stimulating -

and even more so of Jesus. Jesus is said to be crucified without cause (cf Jn 15:25, Lk 12:34, Jn 11; Girard 1982:125-140). At the same time, Jesus' death exposes and defeats the pattern of scapegoatism. Jesus becomes the "Lamb of God" and breaks the evil power of scapegoatism (Girard 1982:221). Thus, according to Girard's thought, it would seem that Jesus gave himself up as a voluntary self-sacrifice, not to appease God's wrath, but rather to enlighten people.

11 The Africans believe that God is the creator of everything including society. Society, according to their belief systems, is a moral entity since the 
challenging people to look differently at their problems. Does it make a difference for the better? It should depend on the situation. In a context where a new spirit is accepted into the community, it does make this kind of difference; where differences between individuals are accepted it probably works as well. But it may sometimes deny or cover-up an evil that should be expelled rather than welcomed (Meiring 2005:167).

The African notion of acceptance can offer a fascinating possibility. Instead of expelling the past, rituals can be devised to accept the past with all its wonder and terror. This may seem dubious to Westerners (the theme of J M Coetzee's Disgrace); like a kind of laissez faire acceptance of evil, but it is seems to work in Africa. It can be especially useful if used among different groups of people in South Africa. As in the example of the Chihamba cult, such a reconciliation model can be used to create a new clan for all South Africans to belong to. Imagine a big ceremony where the past is accepted by all and a new South African race or a people are born. It can overcome a lot of our present difficulties (Meiring, 2005:186).

Archbishop Njongonkulu Ndungane (2003:103) explains that the African emphasis on acceptance is thoroughly Christian:

When we refuse to allow difference in our communities and when we ostracize those who are the 'other', we deny ourselves and others to opportunity to be fully human. African culture invites us to embrace the 'other' and to discover a fuller and

Creator provided a moral code which directs individual behaviour patterns. However, this moral code can be violated, and any infraction of it is regarded as sin, which earns the displeasure of God. Such sinful acts include immoral behaviour, breaking covenant, ritual mistakes, breaking of taboos, committing an abominable act, offence against God or man and pollution. Thus, African Religion tends to locate the source of evil firmly in the human world, in the disruptive ambitions and jealousies of people. What traditional Christianity abstractly calls "sin" or "evil" is better expressed in African religion by the concept of "wrongdoing", "badness" or "destruction of life". Although the more abstract notions of sin exist within the African religious consciousness, African religion's moral perspective is concrete and pragmatic. The African concept of sin is therefore conditional. Sin does not exist in an absolute sense but always within the community and creation. Sin depends on the context and community, and not only otherworldly norms (Magesa 1997:161; Maimela 1985:65; Mbiti 2005:1; Ndwandwe 2000:213; Thorpe 1991:114; Turaki 1999:141; Ubruhe 1996:18). 
richer humanity. This understanding of our humanity echoes, of course, the profound insights offered by the Christian doctrine of the Trinity, which celebrates a loving communion of free, self determining, creative persons.

Ndungane adds that we now have the opportunity to challenge the exclusivism which prefers men above women, whites above blacks, rich above poor, and straight above gay, because our Triune God invites us to demonstrate that in our very differences, we can embrace one another, celebrating otherness, and discovering our deep, Godly unity in those differences (Ndungane 2003:107).

The acceptance model may create a new South Africa where people are not categorised by the colour of their skin, their language or tribal loyalties, but first and foremost as South Africans. It can bring about a new culture, a new shared worldview, and a shared dream. There is no classical corresponding reconciliation model for this idea, but still it can be used to explain the work of Christ. The apostle Paul and others frequently express the idea of a new family. Christ can be said to be the founder of a new community.

Although this kind of thinking goes against traditional Western instincts, Africa may have a point. Some kinds of 'evil' should probably be accepted and dealt with, rather than denied. This reflects a postmodern view that suffering and death are natural phenomena and should not be treated as a moral dilemma (Herholdt 1998:227).

Acceptance, of course, does not mean that everything goes. Inus Daneel (1989:326-329) values the African notion of acceptance, but cautions that it may at times obscure evil or wrongdoing. Sometimes the easy acceptance may not acknowledge that someone is being hurt or that some practices may be bad. On the other hand, an African theologian like Tutu consistently emphasises justice as a prerequisite for reconciliation, but then, restorative justice.

Huber (1990:43) adds that reconciliation demands change on both sides of the conflict. In his reflection on the parable of the prodigal son, he shows that not only younger son had to change but so did his father and older brother. They both had to accept the younger son. The reconciliation model of acceptance especially calls for change in the (supposedly) innocent party or community. 


\subsection{Rebellion}

The strange rituals of rebellion integrate with African thinking in that they seek to uphold the all-important balance within creation. Furthermore, the acts of rebellion are focussed on the potential sources of trouble such as the authority of the chief or animosity between in-laws, and in doing so transcends the expected structures and practices of society. It does seem to make a difference (Meiring 2005:168).

It is harder to imagine how exactly this ritual can explain the work of God in Christ. Can Christ be seen as a divine provocateur? This concept seems almost blasphemous but maybe Luke would have liked it? There may arise circumstances when the establishment is so unjust and seemingly unshakable that one needs to understand Jesus as the divine provocateur and when Christians may feel called to provoke. It also offers new, empowering possibilities for reconciliation among individuals (Meiring 2005:176).

The rituals of rebellion seem strange and offensive to the traditional idea of harmonious and structured reconciliation. These rituals challenge the norms and break down structures and disturb the peace and quiet of society. But this may at times be necessary to achieve true reconciliation. Other cultures may have had the same idea; the similarity between the rituals of rebellion and the Roman Saturnalia festival or the cult of Dionysius is obvious, and so is perhaps even the annual dethronement and enthronement ceremony of the Babylonians. The idea is that power should at times be tempered and established society confronted in order to find reconciliation. In the West we have the principles of democracy but these speak only to the realm of politics and do not impact on our religiosity (Smart 1969:319-320; Meiring 2005:201).

True Christian reconciliation does not always bring about simple harmony, but rather challenges and stirs society. Stephanie Mitchem (2002:260) stresses this idea when saying: "reconciliation challenges all oppressive, dehumanizing systems, not merely restoring the former order, but rebalancing the old so that a new heaven and earth can begin".

According to Bernard Connor (1998:72-73), there is a difference between mediation and reconciliation: a mediator seeks to lessen the hostility between conflicting parties by persuading each to curb their belligerency, tone down their demands and concentrate 
attention on what they have in common; in contrast, true reconciliation that seeks to put all social relations on a new basis may provoke further division and conflict. Connor (1998:72) writes that "reconciliation depends upon conversion taking place".

Those who speak of reconciliation when they are appealing for compromise to reduce overt conflict or a lesser degree of violence have lost the meaning of the term as it is used in Christian theology. Reconciliation is much more far reaching than mediating between enemies to obtain a better modus vivendi, where those in the wrong - and they may be on both sides - still retain their basic antagonistic positions. Arranging a ceasefire or a truce, obtaining a milder form of oppression, or a slightly more just arrangement, may (or may not depending on the circumstances) be a tactical goal worth pursuing. Identifying such goals with 'reconciliation' debases them.

(Connor 1998:73)

Reconciliation by way of rebellion certainly represents the view of Black theology which views Christ as the one who overcomes all obstacles. These obstacles not only include physical ills such as blindness and leprosy but also social ills like poverty and powerlessness (Kiogora 1998:337). This view of reconciliation requires the confrontation of racism:

Black Theology contends that that it is as people candidly face the racial factors that breed alienation and conflict that they will be open to the transformative power of the gospel, which will lead Whites and Blacks to acquire qualitatively new ways of becoming human in their relationships with one another.

(Maimela 1998:117)

African Women's Theology adds that reconciliation means being freed from structures that hold vulnerable members of society, and especially women, in bondage. Achievement of reconciliation would then require challenging all power structures, prejudices and social norms (Oduyoye 1998:363).

Dirkie Smit (2002:108) and Wolfgang Huber (1993:590) reiterate these sentiments when they call attention to the importance of anamnetic solidarity: "This solidarity has to be oriented toward the destiny of the weaker, to the suffering of the victims. A 
preferential option for the victims instead of for the heroes is the appropriate way to deal with history" (Huber 1993:590).

\section{LITURGIES}

Smit (2002:100) believes that liturgy holds the key to the development of theology and that new theological insight relies on creative liturgies that reflect the lives and faith of believers. The African insights can also be translated into new liturgies of community, acceptance and rebellion, as a number of examples show.

\subsection{Community liturgy}

Archbishop Desmond Tutu wrote a moving litany of wholeness that echoes African thought and makes use of Christian theology:

Busy, normal people: the world is here.

Can you hear it wailing, crying, whispering?

Listen: the world is here.

Don't you hear it,

Praying and sighing and groaning for wholeness?

Sighing and whispering: wholeness, wholeness, wholeness?

An arduous, tiresome, difficult journey towards wholeness.

God, who gives us strength of

Body, make us whole.

Wholeness of persons: well-being of individuals.

The cry for bodily health and spiritual

strength is echoed from person to

person, from patient to doctor.

It goes out from a soul to its pastor.

We, busy, "normal" people: we are sick.

We yearn to experience wholeness in our innermost being:

In health and prosperity, we continue to feel un-well

un-filled, or half-filled.

There is a hollowness in our pretended

well-being:

Our spirits cry out for the well-being of

the whole human family.

We pride ourselves in our traditional

Communal ideology, our extended family.

The beggars and the mad people in our streets: 
Where are their relatives?

Who is their father? Where is their mother?

We cry for the wholeness of humanity.

But the litany of brokenness is without end.

Black and white;

Rich and poor;

Hausa and Yomba;

Presbyterian and Roman Catholic:

We are all parts of each other,

We yearn to be folded into the fullness

of life - together.

Life, together with the outcast,

The prisoner, the mad women,

The abandoned child;

Our wholeness is intertwined with their hurt,

Wholeness means healing the hurt,

Working with Christ to heal the hurt,

Seeing and feeling the suffering of others,

Standing alongside them.

Their loss of dignity is not their loss:

It is the loss of our human dignity,

We busy, "normal" people.

The person next to you: with a different

language and culture,

with a different skin or hair colour -

it is God's diversity, making an unbroken

rainbow circle -

our covenant of peace with God, encircling

the whole of humanity.

Christians have to re-enact the miracle

of Good Friday:

the torn veil, the broken walls, the

bridge over the chasm,

The broken wall of hostility between

the Jew and the Gentile.

The wall between sacred and secular?

There is no wall

There is only God at work in the whole;

Heal the sores on the feet;

Salvage the disintegrated personality;

Bind the person back to the whole.

For without that one, we do not have a whole.

Even if there are ninety-nine: 
Without that one, we do not have a whole.

God, who gives us strength of

body, make us whole.

(Tutu 1996:110-113)

\subsection{Liturgy of Acceptance}

A Dinka prayer from the Sudan hints at the new possibility of acceptance:

And though I behold a man hate me,

I will love him.

O God, Father, help me, Father!

O God, Creator, help me, Father!

And even though I behold a man hate me,

I will love him.

(Tutu 1996:101)

From Ghana comes an accepting prayer, written specifically for Africa, which is very applicable to the South African situation:

O Lord, o Ruler of the world,

O Creator, O Father,

this prayer is for Africa.

For our brothers in the South,

for our brothers in the North.

You know

that the white brothers have made their black brothers

second-class people.

O Lord, this hurts us so much.

We suffer from this.

You have given us a dark skin

so that we may better bear

your strong sun.

Why have our brothers done this to us?

They are not better than we, and we are not better than they.

What comforts us is

that you always love most

those who suffer most.

We call ourselves Christians on both sides.

But we go to different churches, as if there were also different heavens.

The white men

still have power in parts of Africa.

Help them, to use their power wisely 
and accept us as brothers.

Take the mistrust out of their hearts and minds

and make them share with us,

for this is our continent,

or, more truly, yours;

and you have marked us for this continent

and them for the North.

We also pray for ourselves.

O Lord,

keep our hearts free from hatred.

And let us also be grateful for what

missionaries have done here

and others too, for government and for the economy.

Let us become brothers again,

as it should be among your children.

You have died for all,

and risen,

Halleluia!

We praise you, our Father,

who are greater than Europe and Africa;

who loves where we hate;

who long ago could have destroyed us.

But you love us so much

and we have not deserved it.

Praise be to you, O Lord!

Amen.

(Tutu 1996:101-103)

\subsection{Liturgy of Rebellion}

Ndungane (2003:104-105) writes that Jesus Christ subverted traditional power structures by washing his disciples' feet and by befriending undesirables and outcasts. To wash each other's feet is a common ritual in churches, especially during the time of Lent, but it is usually explained differently. The same ritual can be used as a ritual of rebellion, as a challenge to the power structures. Ndungane suggests that the ordination of women should be a big priority for the church. The unsanctioned ordination of women (and other marginalised people) would also be a ritual of rebellion that confronts the current injustices.

Albert Nolan (1988:158-159) believes that singing and dancing was the "most visible and most characteristic manifestation of the struggle". He suggests this as a powerful ritual against oppressive 
structures and explains that singing and dancing expresses a hope for a new world and is a celebration of solidarity and unity.

The Confession of Alexandria is a call for struggle and thus a liturgy of rebellion:

We have spoken against evil when it was convenient. We have often avoided suffering for the sake of others, thus refusing to follow His example (1 Pt 2:21). We have preferred religiosity to what the Holy Spirit might be whispering to us. We have struggled against colonialism and many other evils and yet have built up again those things which we had torn down (Gl 2:18). We confess that we had often condoned exploitation and oppression by foreigners. When we have condemned these evils we have condoned the same things by our people. We have turned a blind eye to the structures of injustice in our societies, concentrating on the survival of our churches as institutions.

We have been a stumbling block for too many. For these and many other sins, we are sorry and ask God to forgive us.

A full understanding of this forgiveness leaves us no choice but to continue the struggle for the full liberation of all men and women, and their societies.

We accept that political liberation in Africa, and the Middle East, is part of this liberation. But the enslaving forces and the abuse of human rights in independent Africa point to the need for a more comprehensive understanding of liberation. Liberation is therefore a CONTINUING STRUGGLE.

Now to Him who is able to do immeasurably more than all we can ask or conceive, by the power which is at work among us, to Him be the glory in the Church of Christ Jesus from generation to generation evermore! (Eph 3:20-21)

(Tutu 1996:49-50)

\section{CONCLUSION}

It seems that African Religion can indeed enrich Christianity. Reconciliation need not only be understood in terms of Augustine's victory model, Anselm's objective or Abelard's subjective models, but could (and at times should) variously entail community, acceptance or rebellion. 
This means that if Christians are serious about the ministry of reconciliation, they must value the importance of the community, at times be willing to accept unlikely people or persuasions, but at other times challenge and confront unjust structures. Simultaneously, these African models hint at new ways of understanding the work of Jesus Christ.

It is not only possible to pass from Christianity to African Religion and back again, but also indispensable. David Bosch (1973:73) once wrote:

I would therefore dare to say that today I understand God better than I used to. This is due above all, of course, to the boundless grace of God, but my increasing understanding of African concepts of God was instrumental in the process. God used the richness of African religious experience to teach me more about his richness.

\section{Consulted literature}

Bediako, K 1995. Christianity in Africa: The Renewal of a Non-Western Religion. Edinburgh: Edinburgh University Press.

Bosch, D J 1973. God through African Eyes in Becken, H J (ed) Relevant Theology for Africa, 68-78. Durban: Lutheran Publishing House.

Connor, B F 1998. The Difficult Traverse: From Amnesty to Reconciliation. Pietermaritzburg: Cluster Publications.

Crafford, D, Boshoff, C W H \& Daneel, M L 1984. Pluralisme as Religieuse Verskynsel: Die Onafhanklike Swart kerke en Bewegings en Groepsverhoudinge in Suid-Afrika. Pretoria: ISWEN.

Daneel, M L 1989. Fambidzano: Ecumenical Movement of Zimbabwean Independent Churches. Gweru: Mambo Press.

Dunne, J S 1978. The Way of all the Earth: Experiments in Truth and Religion. Notre Dame: University of Notre Dame Press.

Eliade, M 1958. Patterns in Comparative Religion. New York: Sheed and Ward.

Girard, R 1982. De Zondebok. Kampen: Kok.

Herholdt, M D 1998. Postmodern Theology, in Maimela, Simon \& König, Adrio (eds), Initiation into Theology: The Rich Variety of Theology and Hermeneutics, 215-229. Pretoria: J L van Schaik.

Huber, W 1990. Conflict and reconciliation. Theologia Viatorum 17 (1990), $38-44$. 
-, 1993. Toward an Ethics of Responsibility. Journal of Religion 73:4 (October 1993), 573-591.

Küng, H 1974. On being a Christian. Suffolk: Fount Paperbacks.

Krüger, J S 1995. Along Edges. Religion in South Africa: Bushman, Christian, Buddhist. Pretoria: University of South Africa.

Kwenda, C V 1999. Affliction and healing: Salvation in African religion. Journal for theology in Southern Africa 103, 1-12.

Magesa, L 1997. African Religion: The Moral Traditions of Abundant Life. New York: Orbis.

Maimela, S S 1985. Salvation in African Traditional Religions. Missionalia 13:2 (1985), 63-77.

-, 1998. Black Theology, in Maimela, Simon \& König, Adrio (eds), Initiation into Theology: The Rich Variety of Theology and Hermeneutics, 111-120. Pretoria: J L van Schaik.

Mbiti, J S 1969. African religions and philosophy. London: Heinemann.

-, 1998. African Theology, in Maimela, Simon \& König, Adrio (eds), Initiation into Theology: The Rich Variety of Theology and Hermeneutics, 141-158. Pretoria: J L van Schaik.

-, 2005. Interview on 20 January.

Meiring, A M 2005. Heart Of Darkness: A Deconstruction of Traditional Christian Concepts of Reconciliation by means of a Religious Studies perspective on the Christian and African Religions. Unpublished dissertation, Pretoria: University of Pretoria.

Milbank, J 1997. Postmodern Critical Augustinianism: A Short summa in Forty-two Responses to Unasked Questions in Ward, Graham (ed), The Postmodern God: A Theological Reader, 265-278. Oxford: Blackwell Publishers.

Mitchem, S A 2002. "To Make the Wounded Whole": Womanist Explorations of Reconciliation, in Ruether, Rosemary Radford (ed), Gender, Ethnicity, and Religion: Views from the Other Side, 247-262. Minneapolis: Fortress Press.

Ndungane, N 2003. A World With A Human Face: A voice from Africa. London: SPCK.

Ndwandwe, H C N 2000. Reading 1 John in a Zulu context: hermeneutical issues. Unpublished dissertation. Pretoria: University of Pretoria.

Ngubane, M D 2004. Interview.

Nolan, A 1988. God in South Africa: The challenge of the gospel. Cape Town: David Philip. 
Oduyoye, M A 1998. African Women's Hermeneutics, in Maimela, Simon \& König, Adrio (eds), Initiation into Theology: The Rich Variety of Theology and Hermeneutics, 359-372. Pretoria: J L van Schaik.

Parrinder, E G 1962. African Traditional Religion: $3^{\text {rd }}$ ed. London: Sheldon Press.

Ruether, R R 2002. Preface, in Ruether, Rosemary Radford (ed), Gender, Ethnicity, and Religion: Views from the Other Side ix-xv. Minneapolis: Fortress Press.

Setiloane, G M 2000. African Theology. Cape Town: Lux Verbi.

Smart, N 1969. The Religious Experience of Mankind. Glasgow: Collins.

-, 1998. The World's Religions: Old Traditions and Modern Transformations. Cambridge: Cambridge University Press.

Smit, D J 2002. In diens van die tale Kanaäns? Oor sistematiese teologie vandag? Ned Geref Teologiese Tydskrif 43(1/2), 94-127.

Thorpe, S A 1991. African Traditional Religions. Pretoria: University of South Africa.

Tlhagale, B s a. The Inculturation Debate: A Southern African Perspective. Pretoria: $\mathrm{s}$ l.

Turaki, Y 1999. Christianity and African Gods. Potchefstroom: PU for CHE.

Tutu, Desmond M 1996. An African Prayer Book. Cape Town: Double Story.

-, 1999. No Future Without Forgiveness. London: Rider.

Ubruhe, J O 1996. Traditional Sacrifice: a Key to the Heart of the Christian Message. Journal for Theology in Southern Africa 95, 13-22.

Van Niekerk, A S 1982. Dominee, are you listening to the drums? Kaapstad: Tafelberg. 